\title{
Prototipe Game Petualangan Pariwisata Sulawesi Utara
}

\author{
Agustinus Kisroh, Dr. Eng. Steven R. Sentinuwo, Brave A. Sugiarso \\ Informatics Engineering, Sam Ratulangi University, Manado, Indonesia \\ E-mail : brayenkisroh22@gmail.com, steven@unsrat.ac.id, brave_elect2000sugiarso@yahoo.com
}

\begin{abstract}
Game adalah kegiatan penyelesaian masalah, didekati dengan sikap yang menyenangkan, game juga sesuatu yang membuat pemain menemukan kesenangan dalam memainkannya. Game yang bagus adalah game yang dapat membuat pengguna berpartisipasi secara aktif dan mempunyai jumlah tantangan yang tepat, tidak terlalu sedikit atau terlalu banyak. Menggunakan 3 Tahap metode perancangan yaitu, Analisa kebutuhan untuk mengetahui user stories, kebutuhan data dan kebutuhan user, berikutnya adalah perancangan proses ini dilakukan untuk membuat storyboard, diagram uml, use case dan activity diagram, dan tahap terakir adalah pengujian dilakukan untuk menguji perangkat lunak black box dan pengujian berbasis grafik

Penelitian ini menghasilkan prototipe game pariwisata sulawesi utara, yang nantinya sudah bisa dimainkan dan dijalankan pada sistem operasi Windows . Game dalam bentuk ekstensi exe. Game sangat mudah dimainkan disemua kalangan usia
\end{abstract}

Kata kunci_Game, Prototipe, Windows / Dekstop.

\section{Pendahuluan}

$\mathrm{P}$ erkembangan teknologi sekarang ini yang begitu pesat, terutama pada bidang informasi dan komunikasi. Secara tidak langsung kemampuan manusia juga harus mengimbangi dan beradaptasi sehingga mampu memanfaatkan kecanggihan teknologi tersebut. Komputer dapat diklasifikasikan dalam berbagai bentuk seperti komputer desktop, telepon seluler atau tablet. Seiring pesatnya perkembangan komputer, game komputer juga berkembang dengan pesat dan menjadi salah satu hiburan utama untuk mengisi waktu luang baik dilakukan bersama atau pribadi.

Para gamers atau sebutan bagi para penggemar game lebih tertarik dengan permainan yang lebih beragam dan interaktif. Hingga akhirnya saat ini telah bermunculan banyak sekali developer game-game baru. dengan menggunakan engine unity game 2D tidak sesulit apa yang dibayangankan para mahasiswa yang kebanyakan berpikir bahwa membuat game itu sulit, dan memerlukan pengetahuan pemograman yang tinggi. Unity memiliki kualitas dan fitur yang mudah dipahami, serta kecanggihan untuk membuat animasi dalam game.

Sulawesi Utara yang dikenal dengan budaya khususnya pariwisata yang indah mendorong saya untuk membuat tugas akhir yang berhubungan dengan budaya pariwisata SULUT yang ada dengan judul tugas akhir yaitu: Prototipe Game Petualangan Pariwisata Sulawesi Utara.

Penulis berharap game ini dapat membantu pemain untuk menambah pengetahuan tentang tempat pariwisata Sulawesi utara.

\section{LANDASAN TEORI}

A. Studi Literatur / Tinjauan Pustaka

Penelitian ini diadopsi dari penelitian sebelumnya, yaitu penelitian dari Michello Suwandi. dengan judul penelitian "Prototipe Game Musik Bambu Dengan Menggunakan Unity 3D. Hasil dari penelitian ini adalah Membuat game 3D yang bertujuan untuk mengetahui jenis musik bambu. persamaan dari penelitian ini adalah Sama menghasilkan game yang bertemakan budaya Sulawesi Utara. dan perbedaannya Menghasilkan game 3D sedangkan penelitian 2D

\section{B. Prototipe}

Prototipe merupakan bentuk awal (contoh) atau standar ukuran dari sebuah entitas. Dalam desain, sebuah prototipe dibuat sebelum dikembangkan atau justru dibuat khusus untuk pengembangan sebelum dibuat dalam skala sebenarnya atau sebelum diproduksi secara bersama.

Keuntungan dari prototipe:

User dapat mempertimbangkan sedikit perubahan selama masih bentuk prototipe.

Memberikan hasil yang lebih akurat dari pada perkiraan sebelumnya, karena fungsi yang diinginkan dan kerumitannya sudah dapat diketahui dengan baik.

User merasa puas. Pertama, user dapat mengenal melalui komputer. Dengan melakukan prototipe (dengan analisis yang sudah ada), user belajar mengenai komputer dan aplikasi yang akan dibuatkan untuknya. Kedua, user terlibat langsung dari awal dan memotivasi semangat untuk mendukung analisis selama proyek berlangsung. [VitaWierl2010]

\section{Game Engine}

Game Engine adalah sebuah perangkat lunak yang dirancang untuk membuat sebuah game. Sebuah game engine biasanya dibangun dengan mengenkapsulasi beberapa fungsi standar yang umum digunakan dalam pembuatan sebuah game. Misalnya, fungsi rendering, pemanggilan suara, network, atau pembuatan partikel untuk special effect. Sebagian besar game engine umumnya berupa library atau sekumpulan fungsi- 
fungsi yang penggunaanya dipadukan dengan bahasa pemrograman. [RickmanRoedman2014]

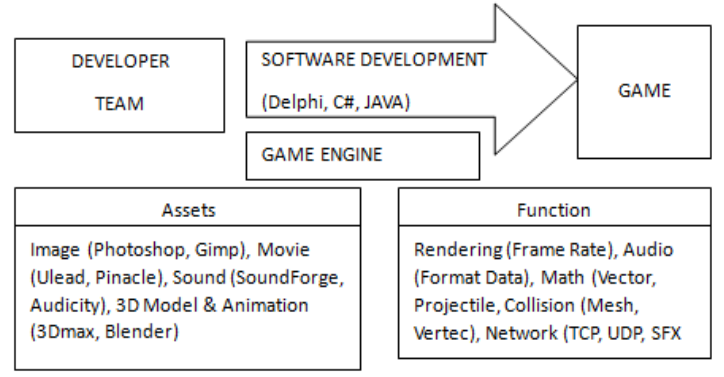

Gambar 1 Game Engine Proses

D. Metode Perancangan

Dalam membuat prototipe game petualangan pariwisata SULUT ini, penulis menggunakan 3 proses tahapapan yaitu :

Analisa Kebutuhan

Analisa kebutuhan dilakukan untuk mengetahui user stories, kebutuhan data, kebutuhan user. User stories dalam hal ini adalah konsep-konsep dasar game seperti jenis mekanisme yang akan digunakan dalam game, jumlah mekanisme dalam game dan ide cerita. Data utama pada game ini adalah gambar pariwisata sulawesi utara. Untuk kebutuhan user, terbagi atas dua bagian yaitu user interface dan fitur-fitur dalam game. Karena game ini dapat dimainkan oleh semua kalangan maka user interface game ini akan disesuaikan sehingga yang main tidak terlalu kekanak-kanakan dan juga tidak terlalu dewasa.

Perancangan

Dalam proses ini yang dilakukan adalah membuat storyboard, diagram uml yaitu use case dan activity diagram. Setelah itu membuat aplikasi.

Pengujian

Prototipe game yang telah selesai dibuat selanjutnya diuji menggunakan teknik pengujian perangkat lunak kotam hitam (Black Box) dengan metode pengujian berbasis grafik yang bertujuan untuk menemukan kesalahan pada antarmuka game.

\section{METODOLOGI PENELITIAN}

\section{A. Analisa Kebutuhan}

\section{Analisis User}

Kuisioner diisi oleh 50 orang pada bulan Juni untuk nantinya digunakan sebagai salah satu acuan pembuatan game. Kuisioner berisikan 5 pertanyaan. Berikut salah satu hasil analisis dari kuisioner yang diberikan:

Apakah anda pernah memainkan permainan yang bertemakan pariwisata daerah?
TABEL I

PERBANDINGAN PERMAINAN BERTEMA KEBUDAYAAN DAERAH

\begin{tabular}{|c|c|c|}
\hline & $\begin{array}{c}\text { Jumlah } \\
\text { Responden }\end{array}$ & Presentase \\
\hline Ya & 4 & $10 \%$ \\
\hline Tidak & 46 & $90 \%$ \\
\hline
\end{tabular}

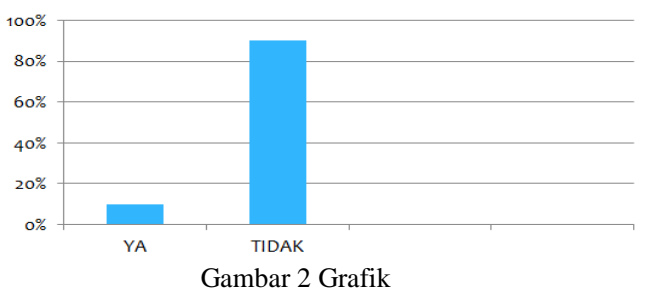

Berdasarkan hasil dari gambar 2 dan grafik 1 terlihat bahwa banyak yang belum pernah memainkan game bertemakan kebudayaan daerah. Data ini akan menjadi dasar pembuatan game ini.

\section{B. Kerangka Pikir}

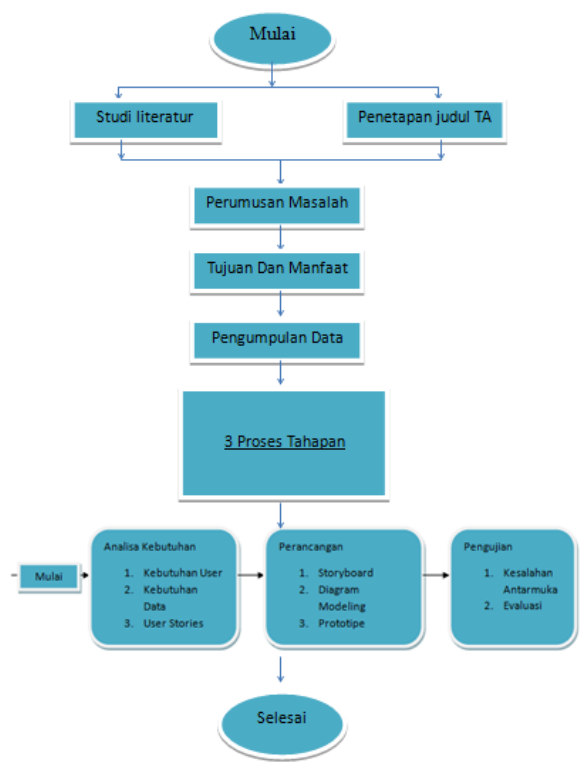

Gambar 3 Kerangka Pikir

\section{Kebutuhan Data}

Data yang digunakan dalam game ini adalah gambar pariwisata sulawesi utara yang nantinya akan dimasukan ke dalam Game Engine. Dalam penelitian ini menggunakan gambar pariwisata sebanyak 15 gambar, sebagaimana akan di uraikan berikut ini.

Objek 2D berupa gambar pariwisata sulut yaitu, objek wisata Yesus Memberkati, Boboca, Bukit Doa, Gunung Mahauw, Danau tondano, Boulevard tondano, Danau linauw, Kaki dian, Batu nona, 
Wisata kebun tangkoko, Pulau lihaga, Pantai pal, Pantai moinit, Bendungan popontolen, Air terjun kali, Danau moat.

\section{User Stories}

\section{Konsep game}

Game ini akan dibuat dalam genre Educational Game dengan mode third-person atau mode dimana pemain akan melihat antar muka dalam sudut pandang orang pertama, kedua dan ketiga. Game ini termasuk genre Educational Game karena dengan memainkannya pemain dapat mengetahui tempat pariwisata sulut. Pemain akan berada di dalam arena yang di dalamnya terdapat terdapat beberapa background gambar pariwisata sulut.

\section{Mekanisme}

Mekanisme yang digunakan dalam game ini yaitu gerak maju-mundur-kiri-kanan-lompat.

Objektif game

Pemain berjalan, lompat dan harus mengumpulkan koin sebagai skor, background game yaitu tempat pariwisata yang ada di sulawesi utara.

Fitur game

Pemain dapat mengontrol pergerakan untuk berjalan di sekitar arena

Saat pemain mengambil koin sebagai skor dan text untuk informasi tempat pariwisata berada di mana.

Teknologi yang digunakan

Bahasa pemrograman Javascript, Game engine Unity 2D, Sistem Operasi Windows 7, Spesifikasi laptop yang digunakan Processor Intel Core i3$4210 \mathrm{U} 1.7 \mathrm{GHz}$, VGA NVIDIA GeForce $820 \mathrm{M}$ RAM 2 GB DDR3, Harddisk 500 GB

Target pemain

Ditargetkan game ini dapat dimainkan oleh semua kalangan usia.

\section{Keunikan game}

Keunikan game ini adalah memberikan pengetahuan kepada pemainnya tentang pariwisata sulawesi utara, sehingga pariwisata sulut lebih ter expose.

\section{E. Perancangan}

Story board

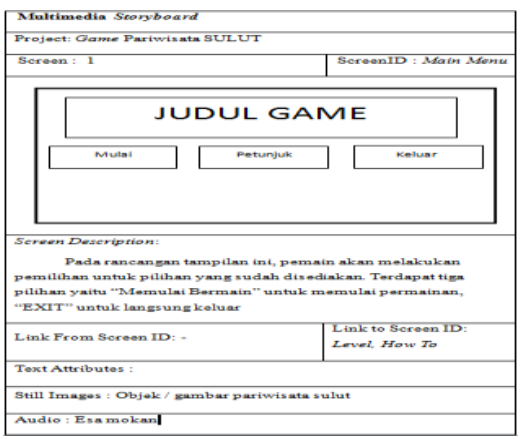

Gambar 2. StoryBoard Game

\section{Use Case Diagram}

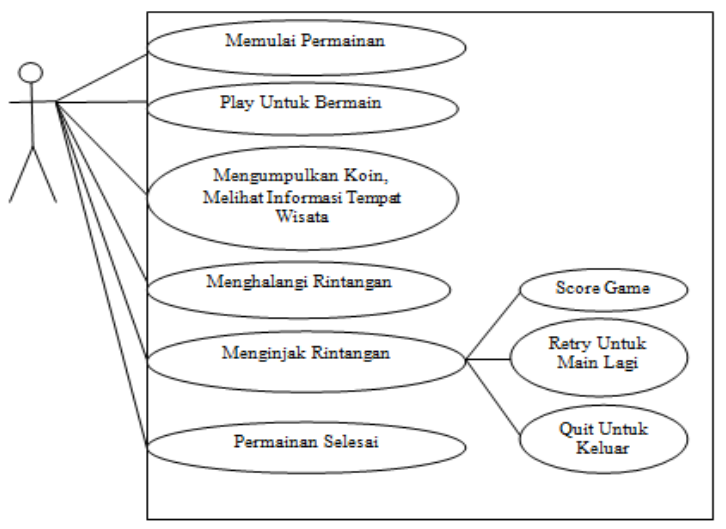

Gambar 3. Use Case Diagram

\section{Activity Diagram}

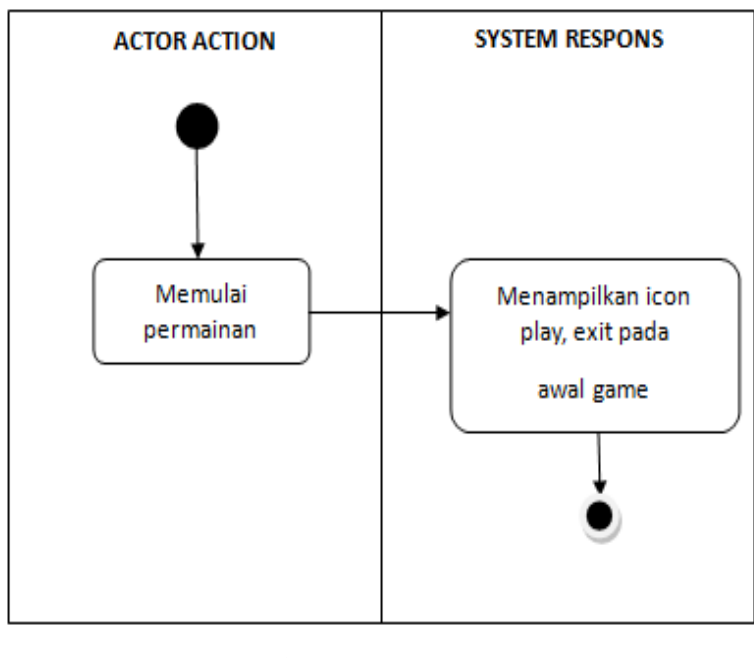

Gambar 4. Activity Diagram

Dari use case diagram gambar 3, pengguna dapat melakukan enam aktifitas memulai permainan, play untuk bermain, Mengumpulkan koin, melihat informasi tempat wisata, menghalangi rintangan, menginjak rintangan, akan menampilkan score game, retry untuk main lagi dan terakir ialah quit untuk keluar, permainan selesai.

Activity Diagram gambar 4, menggambarkan berbagai alur kegiatan secara umum yang ada di dalam game, mulai dari awal dimulainya game, decision yang akan terjadi dan sampai berakhirnya. Activity Diagram ini terbagi atas dua diagram, yang pertama dimulai dari Scene menu utama, yang kedua yaitu pada Scene permainan. 
IV HASIL DAN PEMBAHASAN

\section{A. Prototipe}

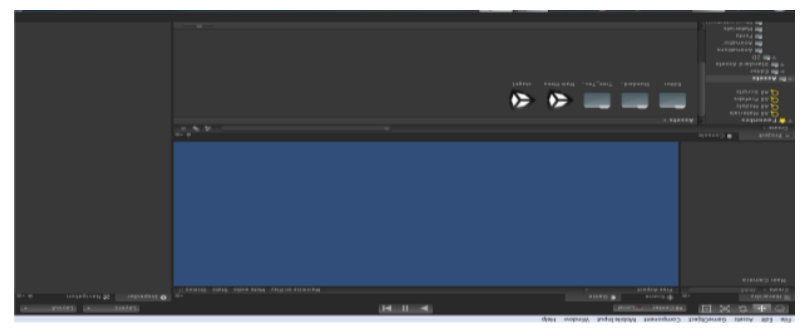

Gambar 5 Tampilan Awal Unity

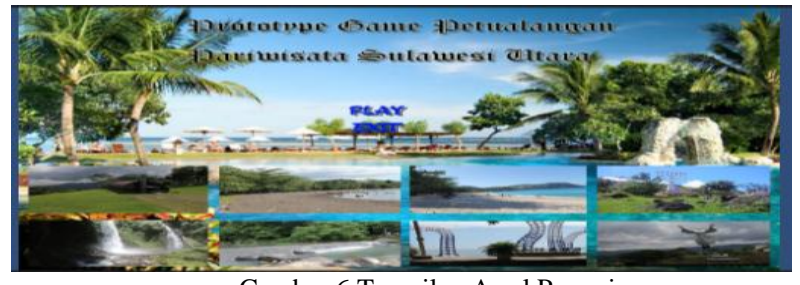

Gambar 6 Tampilan Awal Permainan

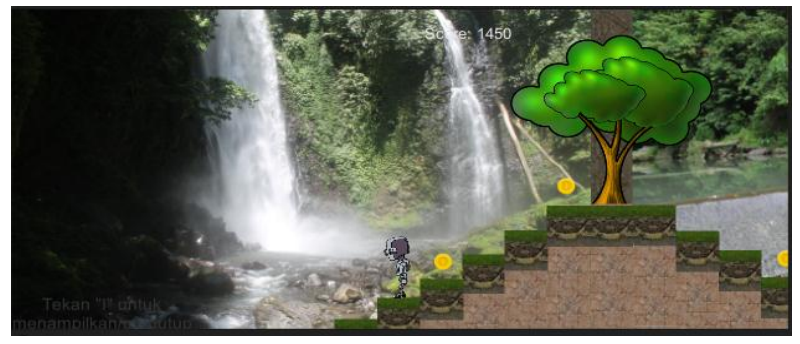

Gambar 7 Tampilan Permainan

Pertama-tama yang harus dilakukan adalah membuka aplikasi Unity sebagai game engine tempat dibuatnya aplikasi. Kemudian membuka project yang telah dibuat (Gambar 4.1)

Akan muncul tampilan menu utama (Gambar 4.2) dimana terdapat judul game dan dua pilihan untuk pemain. Pada menu utama ditampilkan beberapa lokasi pariwisata SULUT.

Akan muncul tampilan permainan (Gambar 4.3) ketika di klik icon play. Dimana tiap tampilan akan menujukan lokasi pariwisata sulut serta informasi yang ada di dalam game tersebut

\section{B. Karakter}

Karakter yang fungsinya untuk mengambil alih permainan dari menghindari rintangan, bergerak maju, mundur, membungkuk dan melompat. Akan game over ketika mengenai rintangan.

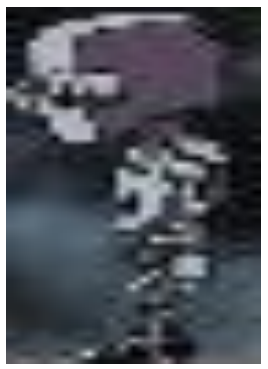

Gambar 8 Karakter

\section{Pengujian Blackbox}

Metode ujicoba blackbox memfokuskan pada keperluan fungsional dari software yaitu fungsi dari tombol main тепи, tampilan permainan, informasi game, animasi rintangan, tampilan game over. Karena itu ujicoba blackbox memungkinkan pengembang software untuk membuat himpunan kondisi input yang akan melatih seluruh syaratsyarat fungsional suatu program.

TABEL II

HASIL PENGUJIAN BLACK BOX

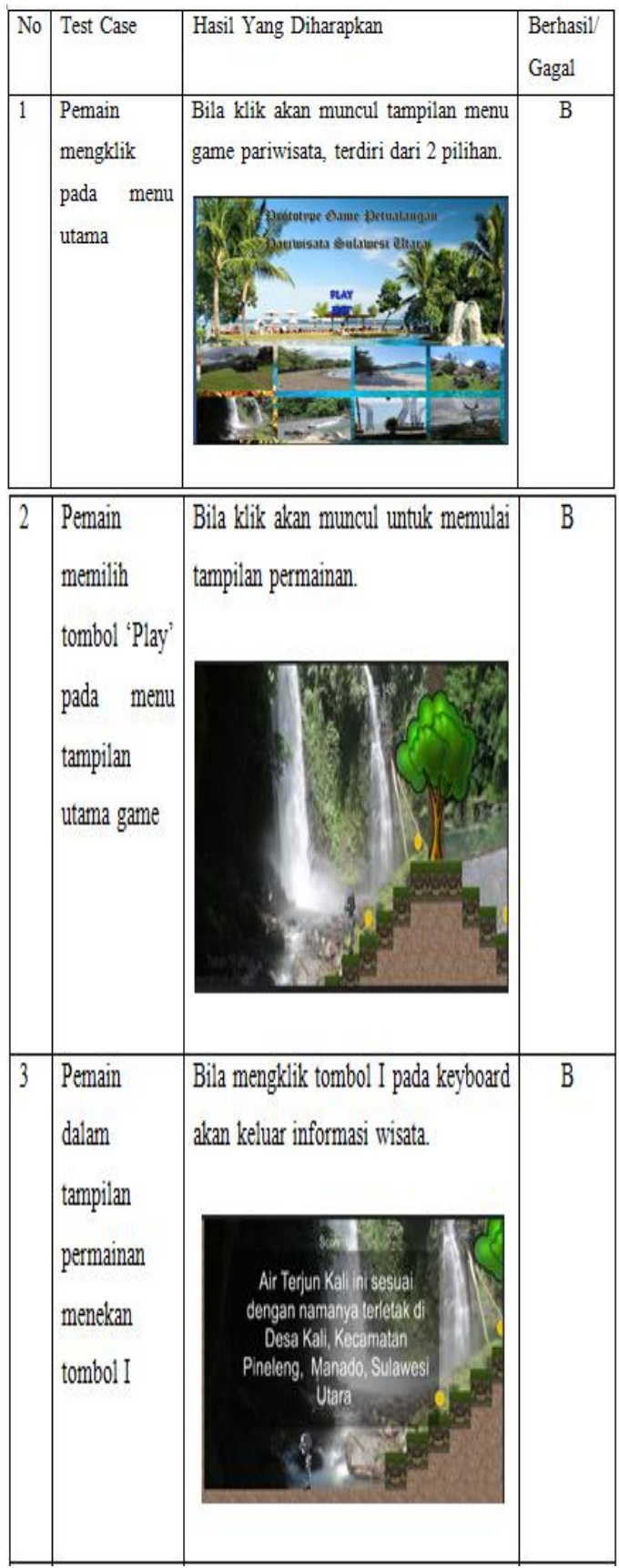




\subsection{Evaluasi Pengguna}

Evaluasi Pengguna dilaksanakan dengan membagikan kuisioner yang berisikan 6 pertanyaan kepada 25 orang responden yang telah memainkan prototipe game 'Petualangan Pariwisata SULUT'.

Apakah game "Petualangan Pariwisata SULUT" mudah untuk dimainkan?

TABLE III

HASIL EVALUASI PENGGUNA TERHADAP TINGKAT KESULITAN PERMAINAN

\begin{tabular}{|l|c|c|}
\hline & $\begin{array}{c}\text { Jumlah } \\
\text { Responden }\end{array}$ & Presentase \\
\hline $\begin{array}{l}\text { Sangat } \\
\text { Mudah }\end{array}$ & 2 & $10 \%$ \\
\hline Mudah & 23 & $90 \%$ \\
\hline Sangat Sulit & 0 & $0 \%$ \\
\hline Sulit & 0 & $0 \%$ \\
\hline
\end{tabular}

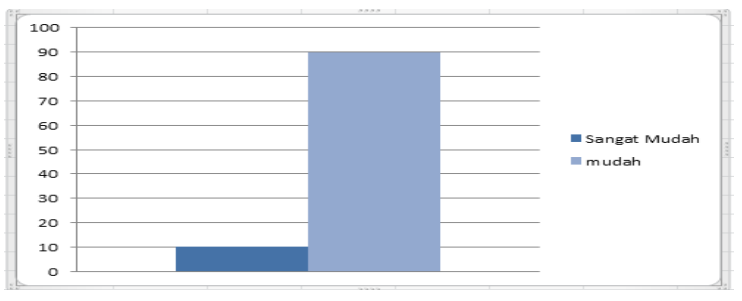

Gambar 9 Grafik Evaluasi

Hasil Evaluasi Pengguna Terhadap Tingkat Kesulitan Permainan Berdasarkan kuisioner yang diisi responden didapat bahwa prototipe game ini mudah untuk dimainkan dengan presentase responden sebanyak $90 \%$ atau sebanyak 23 orang

Kesimpulan:

\section{KESIMPULAN DAN SARAN}

Kesimpulan yang didapat:

Game yang dibuat berupa prototipe, dan secara keseluruhan berdasarkan pengujian blackbox telah berhasil di jalankan.

Menghasilkan prototipe game yang menggunakan Unity 2D yang mengatur keseluruhan sistem permainan juga memanfaatkan fitur Script Editor.

Saran:

Saran pengembangan sistem kedepannya:

Perlu ditambahkannya keseluruhan objek pariwisata SULUT agar pemain dapat mengetahui lebih banyak tempat pariwisata di Sulawesi Utara.

Info dari setiap rintangan perlu di buat lebih jelas dan menarik.

\section{DAFTAR PUSTAKA}

[1] A. Nugroho, Rekayasa Perangkat Lunak Menggunakan UML dan Java. Penerbit Andi, (Yogyakarta, 2010).

[2] R. S Pressman, Rekayasa Perangkat Lunak - Pendekatan Praktisi. Edisi 7: Penerbit Andi, (Yogyakarta. 2010)

[3] S. Michello, Suwandi. Prototipe Game Musik Bambu Dengan Menggunakan Unity 3D. Skripsi Program S1 Teknik Informatika Universitas Sam Ratulangi (Manado, 2014)

[4] R Rickman, Unity Tutorial Game Engine, .Penerbit Informatika, (Bandung, 2014)

[5] W. Santo, MODEL PROTOTYPE SISTEM ERP MODUL PEMBELIAN DAN PENJUALAN UNTUK MENINGKATKAN PRODUKTIFITAS PADA KOPERASI KONSUMSI DI INDONESIA. (Indonesia, 2014)

[6] W.Vita, KONSEP DASAR PROTOTIPE (Indonesia, 2010)

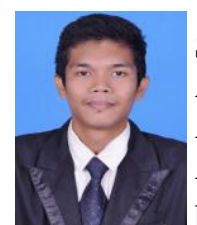

Sekilas dari penulis dengan nama lengkap Agustinus Kisroh, lahir pada tanggal 22 Agustus 1992 di kota Manado Sulawesi Utara. Anak ke 4 dari 4 bersaudara dengan memulai pendidikan sekolah dasar d SD Negeri 21

Manado. Kemudian pada tahun 2004 melanjutkan ke Sekolah Menengah Pertama SMP Negri 8 Manado dan pada tahun 2007 melanjutkan ke SMK Negri 1 Manado. Setelah lulus pada tahun 2010 penulis melanjutkan ke Perguruan Tinggi tepatnya di Universitas Sam Ratulangi Manado dengan mengambil jurusan Teknik Informatika. Pada tahun 2014 bulan November penulis membuat skipsi demi memenuhi syarat sarjana (S1) dengan penelitian yang berjudul Prototipe Game Petualangan Pariwisata Sulawesi Utara yang di bimbing oleh kedua dosen Teknik Informatika Dr. Eng. Steven Sentinuwo, ST., MTI dan Brave. A Sugiarso, ST., MT sehingga pada tanggal 23 Oktober 2015 penulis resmi lulus di Teknik Informatika Universitas Sam Ratulangi dan menyandang sebagai Sarjana Komputer dengan predikat sangat memuaskan. 